\title{
The Australian Year of Women in Local Government: 2010 and beyond
}

\section{Commonwealth Journal of Local Governance}

Issue 7: November 2010

http:/lepress.lib.uts.edu.au/ojs/index.php/cjlg

\section{Karen Purser ${ }^{1}$}

Australian Centre of Excellence for Local Government

Sydney, Australia

\section{Helen Diggerson ${ }^{2}$}

Local Government Managers Australia

Melbourne, Australia

\section{Introduction}

2010 was the Australian Year of Women in Local Government. This paper provides some background information on the Year, an outline of the activities undertaken and some thoughts on how to take the agenda forward beyond 2010.

The most recent Equality and Human Rights Commission's (UK) report, Sex and Power 2008 Index was damning about the future prospects for women being equally represented in the UK Parliament. It looked at women in top positions of power and influence across the public and private sectors over the past five years, and suggests a worrying trend of reversal or stalled progress. Current data suggests the situation is not any better in Australia. Although half the population, women in local government account for only $30 \%$ of elected representatives and only $20 \%$ of senior managers in local government. Moreover, only seven percent of women are chief executive officers.

\footnotetext{
${ }^{1}$ Karen Purser is also the coordinator of the Australian Local Government Women's Association (ALGWA) 50:50 Vision - Councils for Gender Equity program. Karen would like to acknowledge the assistance of Daniel Grafton and Su Fei Tan from the University of Technology, Sydney in preparing this piece.

${ }^{2}$ Year of Women in Local Government Coordinator, Local Government Managers Australia.
} 
Despite many initiatives to increase women's representation in executive and elected leadership roles in local government, this imbalance has been the status quo for the last 20 years. For this reason alone, the need to recognise, value and promote women in local government is as great as ever. Even more pressing is the fact that over the next decade, the majority of senior local government executives will become eligible to retire, and as suggested above, $80 \%$ of these are male. This is a significant opportunity for the sector to address gender imbalances. Without more women managers, executives and elected representatives, the local government sector simply does not have the depth of talent, experience and skills to meet the challenges that lie ahead. In addition, for local government to strengthen policy debate and ensure local decision making represents and meets the needs of the communities it supports, both management and elected representatives must reflect the gender balance and social diversity found within their communities. Thus there are both equity and compelling business cases to promote workplace diversity and increase the participation of women in executive and elected leadership roles.

\section{Background}

The Australian Local Government Women's Association (ALGWA) is a key organisation supporting women in local government. ALGWA aims to assist in furthering women's knowledge and understanding of the functions of local government, and to encourage women to participate and make a career in the sector. In 2007 ALGWA conducted a review of the National Framework for Women in Local Government called The Way Forward. ${ }^{3}$ In early 2008 the national board of Local Government Managers Australia (LGMA) voted to support ALGWA in attracting the necessary resources and commitment from the Commonwealth government and other stakeholders to implement the findings of the review. Additionally, they developed a proposal for a Year of Women in Local Government for 2010. This dedicated Year was envisaged as the basis for an ongoing national program to involve all local government professional peak bodies, state divisions of the LGMA, ALGWA and local councils towards a single aim of increasing women's participation.

In 2009 ALGWA again reviewed the National Framework for Women in Local Government and launched a number of initiatives under the banner 50:50 Vision.

\footnotetext{
${ }^{3}$ See $<$ http://www.lgma.org.au/downloads/File/ALGWA\%20The\%20Way\%20Forward.pdf $>$
} 
The Local Government and Planning Ministers' Council (LGPMC) is another important organisation that has helped facilitate the longer term promotion of increased women's participation. The LGPMC is made up of ministers from across Australia as well as the President of the Australian Local Government Association (ALGA). In October 2009 the LGPMC strongly endorsed ALGWA's 50:50 Vision and released its own Women in Local Government Strategy 2009-12. Under the strategy, the LGPMC committed to a nationally consistent, five-part program of action to improve the participation and status of women in local government, both as elected members and as senior staff. The ministers agreed to:

- Support goals for increasing women's participation

- Support the establishment of an ongoing database on women's participation

- Incorporate women's participation into the proposed local government workforce strategy

- Support the establishment of a national awards and accreditation program that promotes gender equity and cultural change in local government

- Support the 2010 Year of Women in Local Government.

The LGPMC has adopted targets for 2020 whereby $40 \%$ of women are elected members, $35 \%$ are mayors, and 30\% are senior staff. As outlined above, currently women are $30 \%$ of elected representatives and only $20 \%$ of senior managers. Ministers also supported the establishment of a national steering committee representative of the federal government, all states and the Northern Territory, ALGA, ALGWA and LGMA. ${ }^{4}$ This committee, chaired by ALGWA, will promote both the LGPMC strategy and the 50:50 Vision program.

The 2010 Year of Women in Local Government sought to re-invigorate commitment to systematic cultural change in local government, while at the same time supporting women and building their capacity to thrive in leadership roles. The primary focus was to raise awareness of the benefits of increasing the participation of women, and the Year provided a clear focus and opportunity to build the business case for this to happen. Activities were coordinated by a broadly-based steering committee.

\footnotetext{
${ }^{4}$ A representative of the Australian Services Union, which covers a large proportion of local government staff, has since been added to the committee
} 


\section{The Year of Women in Local Government: Some key activities}

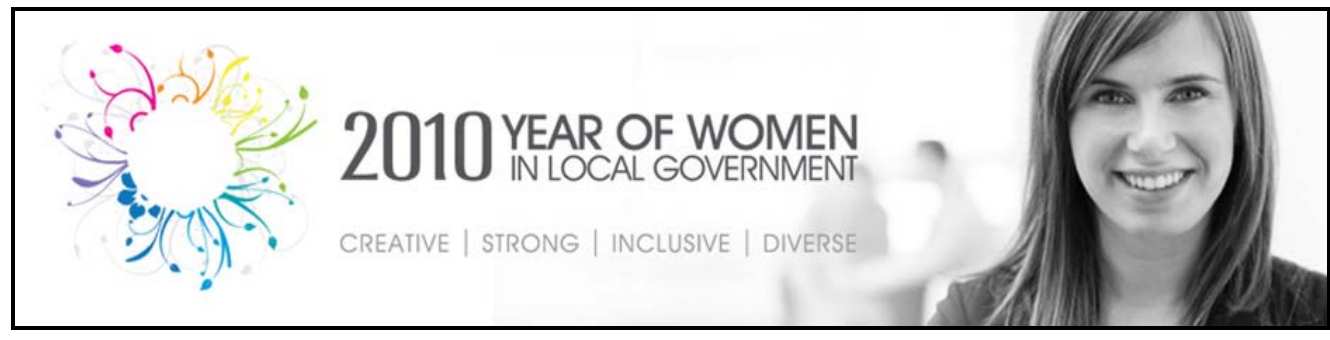

Year of Women in Local Government website banner

Throughout 2010 numerous activities were carried out under the Year of Women in Local Government banner, and many councils undertook a variety of independent initiatives to address gender equity issues. State branches of ALGWA, local government associations, and the LGMA also conducted various networking, mentoring and training programs. An outline of key achievements for the year follows.

\section{Ambassadors}

The steering committee appointed as Ambassadors 21 outstanding women and men who were nominated by their councils as having made significant contributions to the advancement of women in local government. The 19 women and 2 men represented a variety of levels and positions including chief executives, elected members, departmental managers and officers, each with a unique story and view on the issue of the role and place of women in Australian local government. The Ambassadors came from each state and territory, acted as role models, hosted events and forums for women in local government, and promoted the Year both within their organisations and externally in their local communities. 


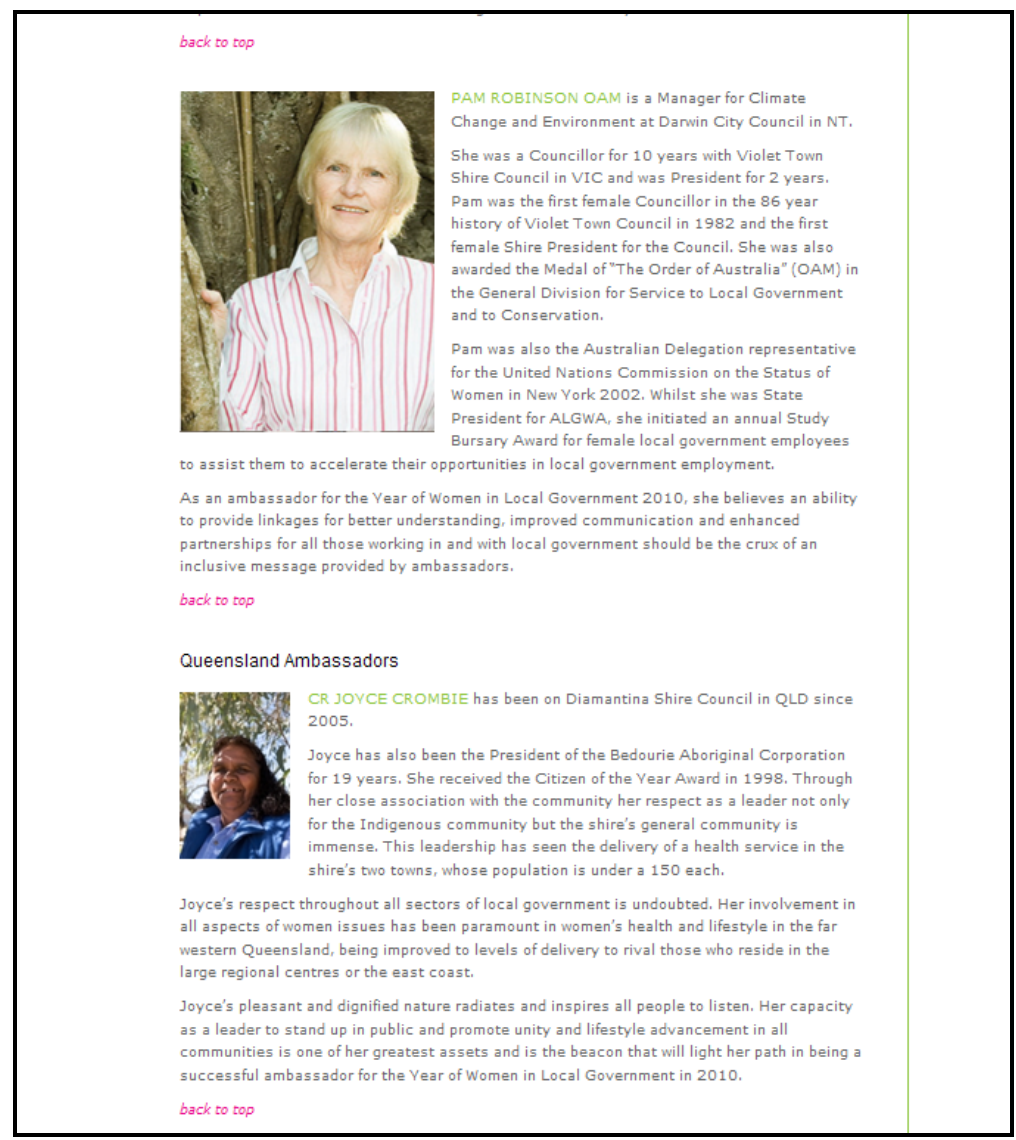

Screenshot of Year of Women in Local Government 'Ambassadors' webpage: <http://lgwomen2010.org.au/ambassadors>

\section{Management Challenge: Pre-challenge task}

Each year the LGMA conducts a 'Management Challenge' that provides executive development for current and emerging local government leaders through real life problem solving and a hands-on approach to leadership development.

The 2010 Challenge attracted 128 teams across Australia and the pre-challenge task (an 'assignment') had the theme of women in local government. Specifically, teams were required to analyse their council's workforce data in order to identify gender barriers and issues, and were encouraged to interview their Mayors and chief executives about the issue. Once the data collection was finalised teams were asked to develop an action plan showing how their council would go about overcoming the particular issues and barriers that emerged. These action plans were then presented to their council's executive management teams. ${ }^{5}$

\footnotetext{
${ }^{5}$ The full report on the Management Challenge Pre-Challenge Task can be read at

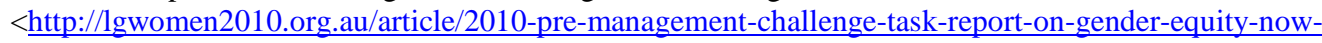
available-for-download>
} 
Whilst the objectives of the pre-challenge task were modest, many teams not only undertook the data analysis and interviews with the chief executive and Mayor, they also conducted focus groups and staff surveys and interviewed senior women in their executive as well as female elected members. Moreover, while the pre-challenge task was designed as a conversation starter many councils took this a step further and responded to the team's action plan.

\section{Australian Local Government Association - Women in politics}

The Australian Local Government Association is the national voice of local government, representing 560 councils across the country. Its key activities are to represent local government on national bodies and ministerial councils, provide submissions to government and parliamentary inquiries, raise the profile and concerns of local government at the national level, and provide forums for local government to guide the development of national local government policies. In June 2010, ALGA released a booklet on Women in Politics at its National General Assembly. This booklet provides an overview of the state of women in local government across Australia including a range of profiles and success stories. Some of people the featured in these stories were also Year of Women in Local Government Ambassadors. ${ }^{6}$

\section{Local Government Women's Charter Project}

The Women's Participation in Local Government Coalition is a non-party political coalition of 8 local government, community and philanthropic organisations, women councillors and individual women in the state of Victoria. It was originally formed in 1996 to work towards the equal participation of women and men in local government. The coalition is resourcing and encouraging local governments to adopt the Victorian Local Government Women's Charter and implement an action plan looking to 2012 and beyond. They also facilitate information sharing across local governments, coordinate and share resources related to women's participation, provide advice and support to nominated women's charter champions, and document actions taken by local government in Victoria to achieve gender equity, diversity and active participation/citizenship.

\footnotetext{
${ }^{6}$ The booklet can be downloaded from the ALGA website $<$ www.alga.asn.au $>$
} 
4. 50:50 Vision - Councils for Gender Equity

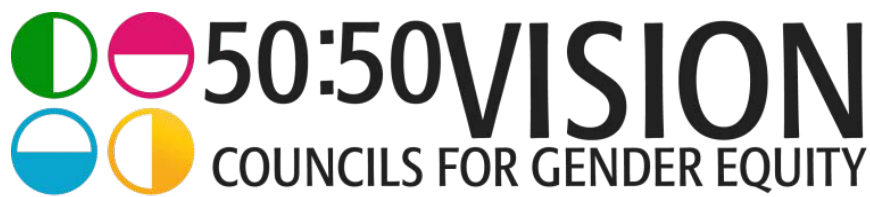

The fourth platform of the LGPMC strategy was to support the establishment of an awards and accreditation program that promotes gender equity and cultural change in local government. This had been proposed by ALGWA as part of its 50:50 Vision. Accordingly, the federal government agreed to provide substantial funding to ALGWA to establish a new program 50:50 Vision - Councils for Gender Equity.

This 10 year program is the first national accreditation and awards program that encourages councils across Australia to address gender equity within their organisations and among their elected representatives. All councils regardless of their size, location or progress on gender equity can participate in this program. Councils can apply for accreditation (sequentially) at bronze, silver and gold levels, and will move along a path of commitment, reflection, policy development and cultural change. It is envisaged that identification of councils as 50:50 Vision employers of choice will make it easier for them to attract and retain female councillors and managers. Councils' participation in the program is encouraged by local government ministers in all states and territories. The first round of bronze awards was presented to 22 councils from across the country at the ALGWA National Conference in November 2010. 


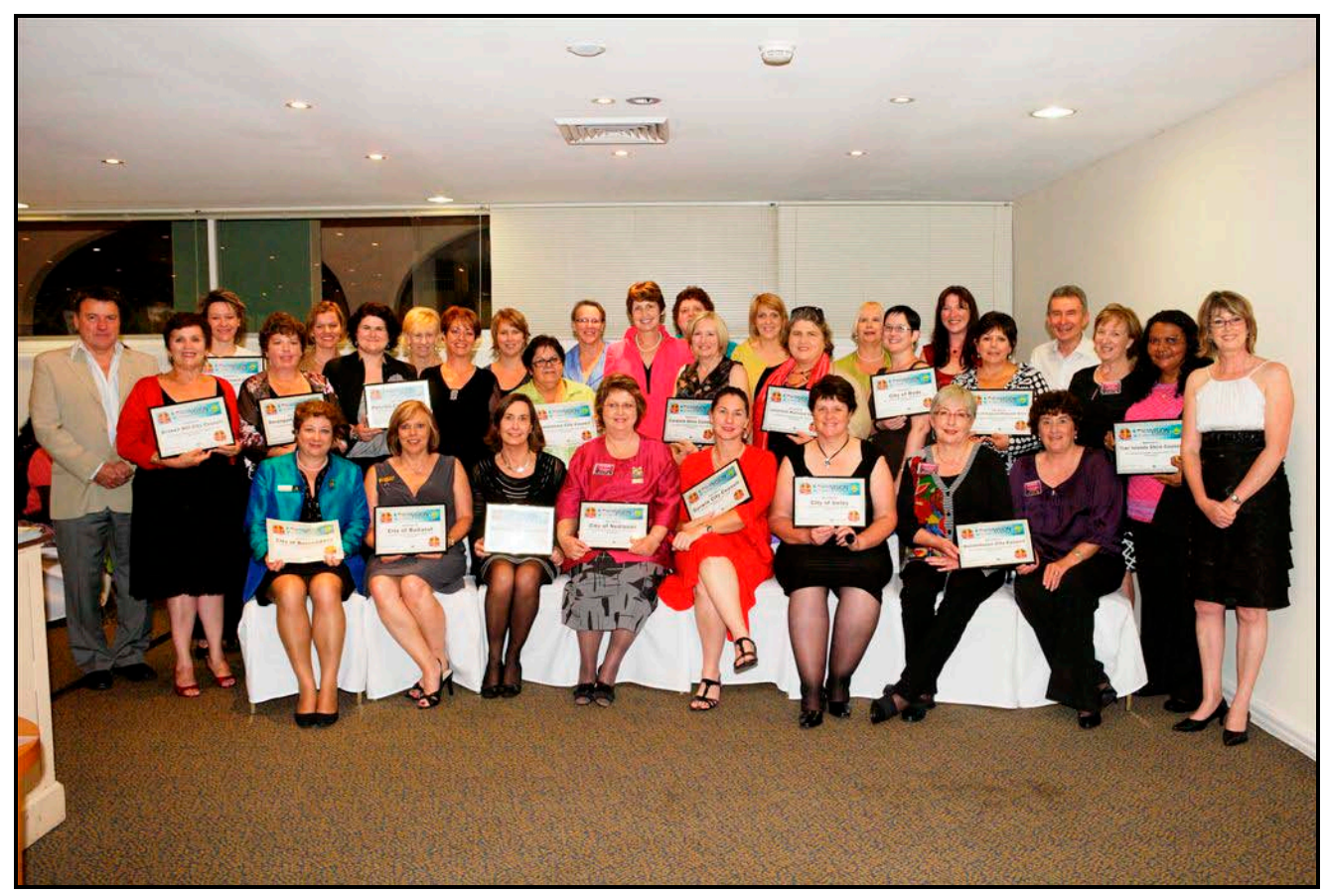

Bronze award winners at the 2010 ALGWA National Conference.

A key feature of the program is the sharing of information among councils, that is, providing a platform for the development of case studies and sector wide discussion about gender equity issues and progress. The program highlights and supports the targets set by the LGPMC and promotes them in much of its material.

\section{2010 and Beyond}

One year of activities to promote women in local government is not enough to bring about gender equity. All the partners involved in the initiatives described above have accepted that cultural and systemic change requires continued commitment and engagement. However the Year of Women in Local Government has done much to raise awareness and put gender equity on the agenda in many organisations. For instance, the Management Challenge has re-invigorated the conversation in many councils, and addition, 100 councils have joined the Year of Women in Local Government Partnership Program and contributed funds to the development and implementation of the Year's activities. Although the involvement of these councils is a good start to achieving change, there are still too many that have not actively engaged in the conversation and need encouragement. One way of achieving this is to continue awareness raising and education on the need for change and to promote good practice, using the new Councils for Gender Equity program as a platform. Also, an updated 50:50 Vision strategy 
document is being prepared, and the LGPMC national steering committee will be strengthened with the appointment of more people who played leading roles in the Year.

Thus the focus on the importance of increased women's participation in local government is stronger than ever; governments are engaged, there have been widespread re-affirmations of support, and the groundwork has been laid for a decade-long effort to achieve - and hopefully exceed - specific targets. Significant progress has been made.

\section{Websites and Useful Links}

- Year of Women in Local Government: www.lgwomen2010.org.au

- 50:50 Vision Councils for Gender Equity: www.5050vision.com.au

- Australian Local Government Women’s Association: www.algwa.net.au

- Australian Local Government Association: www.alga.asn.au

- Local Government Managers Association: www.lgma.org.au 